\title{
Okara, a soymilk industry by-product, as a non-meat protein source in reduced fat beef burgers
}

\author{
Okara, um sub-produto da indústria de leite de soja, como fonte de proteina \\ não cárnea em hambúrguer bovino com reduzido teor de gordura
}

\author{
Simone Ing Tie SU${ }^{1}$, Cristiana Maria Pedroso YOSHIDA ${ }^{1}$, Carmen Josefina CONTRERAS-CASTILLO², \\ Eliane Marta QUIÑONES ${ }^{3}$, Anna Cecilia VENTURINI ${ }^{1 *}$
}

\begin{abstract}
Okara is a by-product generated during the manufacture of soymilk and tofu. Wet okara was added to beef burgers at $0 \%, 20 \%$, and $25 \%$. The effects of okara on certain physicochemical, textural, and sensory properties of reduced fat beef burgers were investigated. The beef burgers formulated with okara $(104.0-106.0 \mathrm{kcal} / 100 \mathrm{~g})$ had $60 \%$ less calories than commercial beef burgers $(268.8 \mathrm{kcal} / 100 \mathrm{~g})$. The texture profile analysis showed that the addition of wet okara led to a significant increase in hardness $(p<0.05)$ and a concomitant reduction in the values of chewiness, springiness, and cohesiveness. Lower sensory scores $(p<0.05)$ of flavour were observed in the beef burgers containing $25 \%$ wet okara. However, the sensory evaluation results showed that juiciness, appearance, tenderness, and overall acceptability of beef burgers formulated with okara did not differ statistically from that of the control (0\% okara). Wet okara (20\%) can be used as a non-meat protein source in the production of reduced-fat beef burgers without changing their sensory quality.

Keywords: beef burger; soy; texture; sensory attributes.
\end{abstract}

\section{Resumo}

Okara é o subproduto gerado na fabricação de leite de soja ou tofu. Okara úmido foi adicionado em hambúrguer de carne bovina nas concentrações de $0 \%, 20 \%$ e $25 \%$. A influência da adição de okara em $0 \%, 20 \%$ e $25 \%$ sobre certas propriedades físico-químicas, de textura e sensoriais em hambúrgueres bovinos com reduzido teor de gordura foi investigada. Os hambúrgueres formulados com okara $(104,0-106,0 \mathrm{kcal} / 100 \mathrm{~g})$ apresentaram $60 \%$ menos calorias do que hambúrgueres comerciais de carne bovina (268,8 kcal/100 g). A análise do perfil de textura mostrou que o aumento da concentração de okara foi acompanhado por um aumento de dureza $(p<0,05)$, com concomitante diminuição dos valores de mastigabilidade, elasticidade e coesividade. Notas sensoriais significativamente mais baixas $(p<0,05)$ para sabor foram observadas nos hambúrgueres contendo $25 \%$ de okara úmido. No entanto, os resultados da análise sensorial mostraram que a suculência, aparência, maciez e aceitabilidade geral dos hambúgueres formulados com okara não diferiram estatisticamente do controle ( $0 \%$ okara). Okara úmido a $20 \%$ pode ser utilizado como fonte de proteína não cárnea para a produção de hambúrguer bovino com gordura reduzida sem alterar a sua qualidade sensorial.

Palavras-chave: hambúrguer bovino; soja; textura; atributos sensoriais.

\section{Introduction}

The most practical method for production of low-fat meat products is fat reduction (ARIHARA, 2006). However, fat greatly influences the overall acceptability of the finished product. Texture is a critical characteristic of meat in terms of consumer acceptability (BREWER, 2012). Several studies have found that reducing the fat level by approximately $20 \%$ to between 5 and $10 \%$ in beef burgers results in lower scores for tenderness, juiciness, flavour intensity, and overall product palatability (DESMOND; TROY; BUCKLEY, 1998). When the total fat content is reduced, optimising the remaining fat content and cooking parameters to produce a high quality finished product is necessary to meet consumer expectations and encourage the consumption of lower fat, lower calorie products (BREWER,
2012). There are several alternative fat substitutes that show potential to improve the palatability of low-fat meat products (DESMOND; TROY; BUCKLEY, 1998).

Okara is a by-product with low commercial value generated during the manufacture of soymilk (LI et al., 2012; PINTO; CASTRO, 2008). Grizotto et al. (2010) estimated that from each ton of processed soybeans, approximately seven tons of soymilk and two tons of okara are produced. By-products generated by the food industry are promising sources of compounds that may be used for their technological, nutritional, and functional properties (MATEOS-APARICIO et al., 2010; SELANI et al., 2011).

\section{Received 3/8/2012}

Accepted 4/10/2012 (00N5823)

Department of Exact and Earth Sciences, Federal University of São Paulo - UNIFESP, Rua Professor Artur Riedel, 275, Jardim Eldorado, CEP 09972-270,

Diadema, SP, Brazil, e-mail: anna.venturini@unifesp.br

${ }^{2}$ Department of Agro-industry, Food and Nutrition, University of São Paulo - USP, Piracicaba, SP, Brazil

${ }^{3}$ Faculty of Food Engineering, Metropolitan University of Santos - UNIMES, Rua da Constituição, 374, Vila Paquetá, CEP 11015-470, Santos, SP, Brazil

${ }^{*}$ Corresponding author 
Okara has high protein content $(40 \%$ on a dry weight basis) with good essential amino acid profile and digestibility (GRIZOTTO et al., 2010; MA et al., 1997). Approximately one-third of the isoflavones present in the soybean remain in okara, suggesting that it is a good, low cost source of nutrients (BOWLES; DEMIATE, 2006; JACKSON et al., 2001). Other components of soy present in okara include lignans, phytosterols, coumestans, saponins, and phytates (TURHAN; TEMIZ; SAGIR, 2007). Despite the high nutritional and excellent functional properties (emulsification, foaming, and binding properties) of okara and its potential for application in food products, the most common use of this by-product is in the manufacture of animal feed (PINTO; CASTRO, 2008). Okara has been used to partially replace wheat flour, cassava starch, corn flour, and soy flour (BOWLES; DEMIATE, 2006; GRIZOTTO et al., 2010; APLEVICZ; DEMIATE, 2007; RINALDI; NG; BENNINK, 2000; WALISZEWSKI; PARDIO; CARREON, 2002). The use of okara as a fat replacer in meat products is still in the experimental stage (TURHAN; TEMIZ; SAGIR, 2007). Meat product reformulation using fat substitutes can increase water holding capacity compared to that of the control, (high fat product); however they produced different effects on texture (BREWER, 2012). Texture is the most important factors in deciding overall acceptance of beef products (SARIÇOBAN; YILMAZ; KARAKAYA, 2009). Therefore, the objectives of this study were to evaluate the effects of the addition of wet okara on the nutritional, textural, and sensory characteristics of reduced fat beef burgers and find optimum TPA indices based on maximum sensory scores of reduced-fat beef burgers.

\section{Materials and methods}

\subsection{Preparation of burger beef samples}

Lean beef ( $6 \%$ fat) meat and pork back fat were obtained from a local hypermarket (Carrefour Comérico e Indústria Ltda, Diadema, SP, Brazil). Frozen wet okara (moisture: 80\%; protein: 4.7\%; fat: $1.5 \%)$ was obtained from a commercial processing plant (Hyde Alimentos Ltda, São Paulo, SP, Brazil) within one day of manufacture and kept frozen at $-18^{\circ} \mathrm{C}$ for up to one week prior to use. Three levels of wet okara addition were assessed with beef burgers: $0 \%, 20 \%$, and $25 \%$. A control formulation (F0) without okara was prepared using the following formulation (adapted from TURHAN; TEMIZ; SAGIR, 2007): 767 g. $\mathrm{kg}^{-1}$ lean beef meat, 50 g. $\mathrm{kg}^{-1}$ fat, $10 \mathrm{~g} . \mathrm{kg}^{-1}$ commercial sodium chloride (Cisne, Cabo Frio, RJ), 5 g. $\mathrm{kg}^{-1}$ sodium polyphosphate (Krakoline E, Kraki, Santo André, SP, Brazil), 1 g. $\mathrm{kg}^{-1}$ sodium erythorbate (Fixador A80S, Kraki, Santo André, SP, Brazil), 10 g. $\mathrm{kg}^{-1}$ burger condiment (Condiment 102, Kraki, Santo André, SP), and $156 \mathrm{~mL} \cdot \mathrm{kg}^{-1}$ water. Other two formulations were prepared by replacing the water and lean beef meat in the control formulation with wet okara (F1 burger contained 723 g. $\mathrm{kg}^{-1}$ lean beef and 200 g. $\mathrm{kg}^{-1}$ wet okara; F2 contained $673 \mathrm{~g} . \mathrm{kg}^{-1}$ lean beef and $250 \mathrm{~g} \cdot \mathrm{kg}^{-1}$ wet okara). Lean beef meat and fat were ground (12 mm plate) in a grinder (Hobart 4B22-2, Troy, Ohio, USA). Immediately after the addition of ingredients, the formulations were homogenised in a cutter (Hobart 84142, Troy, Ohio, USA). From the homogenised meat mixture, burgers of $80 \mathrm{~g}$ each were shaped approximately $8 \mathrm{~cm}$ in diameter and $1 \mathrm{~cm}$ in thickness. The samples were frozen $\left(-18^{\circ} \mathrm{C}\right)$ prior to analysis. The beef burgers were placed on a grill, cooked on one side to an internal temperature of $40{ }^{\circ} \mathrm{C}$, and then turned and cooked to a final internal temperature of $72{ }^{\circ} \mathrm{C}$ before the texture profile and sensory analyses.

\subsection{Proximate composition}

The methods of AOAC (ASSOCIATION..., 2007) were used to determine the moisture, ash, total lipid content and total protein (conversion factor of 6.25 from total nitrogen to total protein) in raw beef burgers. Total carbohydrate content was calculated by the subtraction of the sum of moisture, ash, total lipids, and proteins. All proximate composition experiments were performed in triplicate and expressed as $\mathrm{g} / 100 \mathrm{~g}$ of burger in wet basis (\%). The total energetic value was calculated using the energy conversion factors (BRASIL, 2003) as follows: total energetic value $(\mathrm{kcal} / 100 \mathrm{~g})=($ protein percentage $\times$ 4 kcal.g $\left.\mathrm{g}^{-1}\right)+\left(\right.$ lipid percentage $\left.\times 8 \mathrm{kcal} \mathrm{g}^{-1}\right)+($ total carbohydrate percentage $\left.\times 4 \mathrm{kcal} \cdot \mathrm{g}^{-1}\right)$.

\subsection{Instrumental colour evaluations}

The surface colour of the raw beef burgers was measured using a portable colourimeter (Konica Minolta CR-400, Osaka, Japan). The colourimeter was calibrated with the following specifications: observation angle of $2^{\circ}$ and illuminant C. The coordinates CIE $\mathrm{L}^{*} \mathrm{a}^{*} \mathrm{~b}^{*}$ readings were performed in triplicate. The hue angle $\left[\left(b^{*} / a^{*}\right) \tan ^{-1}\right]$ and saturation index $\left[\left(a^{\star 2}+b^{* 2}\right)^{1 / 2}\right]$ of the burgers were also calculated. This measurement was repeated at five randomly selected locations for each beef burger exposed at room temperature for approximately $1 \mathrm{~h}$ so that the temperature of the refrigerated product was in equilibrium with the environment avoiding the condensation of water vapour in the apparatus.

\subsection{Texture profile analysis (TPA)}

Texture Profile Analysis (TPA) was performed using a texture analyser (Brookfield Engineering, CT3-50K, Middleboro, MA, USA) coupled to a computer interface. Cubes $\left(2 \mathrm{~cm}^{3}\right)$ of cooked samples at room temperature were compressed axially in two consecutive cycles of $50 \%$ compression using an aluminium cylinder probe $\mathrm{P} / 36$ (36 mm diameter, Brookfield Engineering, Middleboro, MA, USA). Data collection and calculations were performed using the Texture Pro Software (Brookfield Engineering, CT3-50K, Middleboro, MA, USA). Force-time deformation curves were obtained with a $50 \mathrm{~kg}$ load cell applied at a cross-head speed of $2.0 \mathrm{~mm} . \mathrm{s}^{-1}$. A trigger force of $5 \mathrm{~g}$ was applied. Analyses of hardness, chewiness, springiness, and cohesiveness were performed in triplicate as described by Bourne (1978).

\subsection{Sensory analysis}

Cooked burgers, with and without okara, were cut into pieces of uniform size $\left(2 \mathrm{~cm}^{3}\right)$ and served warm $\left(45^{\circ} \mathrm{C}\right)$ to 28 judges recruited among the staff and students of the University, 
who had no prior knowledge of the formulation of the products (STONE; SIDEL, 1993). All samples were coded with three-digit random numbers and presented in a randomised order. The judges evaluated the attributes of taste, flavour, appearance, texture, and overall acceptability using a 9-point verbal hedonic scale $(9=$ liked extremely to $1=$ disliked extremely $)$. Acceptability index was expressed as a percentage according to Teixeira, Meinert and Barbetta (1987). The present study was submitted to the Ethics Committee for Research of the Federal University of São Paulo - UNIFESP and approved (approval number: 184069/11) in accordance with Resolution 196/96 of the Brazilian National Health Council on research involving human subjects.

\subsection{Statistical analysis}

The control treatment was the reduced fat beef burger without okara. The experiment was replicated twice, and the means were calculated by analysis of variance (ANOVA) using Statistica ${ }^{\mathrm{TM}}$ (Statsoft Inc., Tulsa, OK, USA). Significant differences between means were determined by the Tukey test. The significance level used for all statistical analyses was 5\%.

\section{Results and discussion}

The results of the proximate composition of the beef burgers are given in Table 1. All of the beef burgers had water/protein ratio of approximately 4:1. Bengtsson, Montelius and Tornberg (2011) found that it is crucial that this ratio remains constant in all formulations in order to enable the comparison of the effects of okara content on the textural properties of beef burger.

The fat content in beef burgers with added okara ranged from $7.2 \%$ to $7.4 \%$, a reduction in fat of approximately $40 \%$ compared with those of commercial products, confirming the purpose of reduced fat beef burgers. According to current legislation (BRASIL, 1998), beef burgers with a minimum $25 \%$ reduction in total fat can be labelled as "reduced fat".
The protein levels of beef burgers with added okara (Table 1) were higher than those found in commercial beef burgers. The caloric value of beef burgers with added okara $(104-106 \mathrm{kcal} / 100 \mathrm{~g})$ was approximately $60 \%$ lower than that of commercial beef burgers $(268.8 \mathrm{kcal} / 100 \mathrm{~g}$ ), confirming the nutritional advantages of burgers made with this non-meat protein source.

The effect of okara content on the textural properties of beef burgers, such as hardness, chewiness, springiness, and cohesiveness, are shown in Table 2.

Hardness is defined as the degree of resistance of the beef burger to scratching (SARIÇOBAN; YILMAZ; KARAKAYA, 2009). Increasing the concentration of okara resulted in an increase in hardness $(p<0.05)$, and this may be related to the reduction in moisture. Products' hardness decrease with increase in moisture content (DAS et al., 2008). Chewiness is defined as the energy required to chew the beef burger (SARIÇOBAN; YILMAZ; KARAKAYA, 2009). Increasing the concentration of okara significantly reduced chewiness values $(p<0.05$, Table 2$)$. Soft texture of soy paste significantly affected the chewiness of soy paste full-fat extended nuggets (DAS et al., 2008). Springiness is how well a product physically springs back to the initial condition during the first compression (YILMAZ; DAGLIOGLU, 2003) and is related to water binding and fat properties (HORITA et al., 2011). Increasing the concentration of okara decreased springiness values $(p<0.05$, Table 2$)$. The significant lower springiness in beef burger made with okara can be due to the partial replacement of meat with wet okara. Cohesiveness, the extent to which food can be deformed before it ruptures (SARIÇOBAN; YILMAZ; KARAKAYA, 2009), was also affected by the concentration of okara. Increasing the concentration of okara significantly reduced $(p<0.05$, Table 3 ) the cohesiveness of the beef burgers.

Table 1. Proximate composition (g/100 g beef burgers in wet basis) and energy (kcal/100 g or kJ.100 ${ }^{-1}$ ) of raw beef burgers.

\begin{tabular}{|c|c|c|c|c|c|c|c|}
\hline \multirow{2}{*}{$\begin{array}{l}\text { Level } \\
\text { okara }\end{array}$} & \multirow{2}{*}{$\begin{array}{c}\text { Moisture } \\
(\mathrm{g})\end{array}$} & \multicolumn{2}{|c|}{ Energy } & \multirow{2}{*}{$\begin{array}{c}\text { Protein } \\
(\mathrm{g})\end{array}$} & \multirow{2}{*}{$\begin{array}{l}\text { Lipids } \\
\text { (g) }\end{array}$} & \multirow{2}{*}{$\begin{array}{c}\text { Carbohydrates } \\
\text { (g) }\end{array}$} & \multirow{2}{*}{$\frac{\text { Ash }}{\text { (g) }}$} \\
\hline & & $\mathrm{kcal}$ & $\mathrm{kJ}$ & & & & \\
\hline $0 \%$ (control) & 71.0 & 96.4 & 403.0 & 16.7 & 7.4 & 0.0 & 0.8 \\
\hline $20 \%$ & 69.6 & 106.2 & 443.8 & 16.7 & 7.4 & 2.7 & 0.8 \\
\hline $25 \%$ & 70.0 & 104.5 & 436.6 & 15.9 & 7.2 & 3.4 & 0.8 \\
\hline commercial $^{*}$ & nd & 268.8 & 1123.6 & 14.0 & 17.0 & 2.2 & nd \\
\hline
\end{tabular}

${ }^{*}$ nutritional information on the commercial product packaging.

Table 2. Mean values ( \pm standard deviations) of instrumental colour $\left(\mathrm{L}^{\star}, \mathrm{a}^{\star}\right.$ and $\left.\mathrm{b}^{\star}, \mathrm{C}^{\star}, \mathrm{h}^{\star}\right)$ of raw beef burgers at $4^{\circ} \mathrm{C}$.

\begin{tabular}{lccccc}
\hline & $\mathrm{L}^{\star}$ & $\mathrm{a}^{\star}$ & $\mathrm{b}^{\star}$ & $\mathrm{C}^{\star}$ & $\mathrm{h}^{\star}$ \\
\hline $0 \%$ & $38.2 \pm 1.6^{\mathrm{a}}$ & $20.1 \pm 1.9^{\mathrm{a}}$ & $14.9 \pm 1.4^{\mathrm{a}}$ & $25.1 \pm 2.0^{\mathrm{a}}$ & $36.8 \pm 1.5^{\mathrm{a}}$ \\
(control) & & & & & \\
$20 \%$ & $44.5 \pm 2.0^{\mathrm{b}}$ & $14.3 \pm 1.5^{\mathrm{b}}$ & $12.6 \pm 3.0^{\mathrm{a}}$ & $19.2 \pm 2.0^{\mathrm{b}}$ & $41.5 \pm 2.0^{\mathrm{b}}$ \\
$25 \%$ & $45.2 \pm 0.9^{\mathrm{b}}$ & $14.6 \pm 1.9^{\mathrm{b}}$ & $13.3 \pm 1.3^{\mathrm{a}}$ & $19.8 \pm 2.2^{\mathrm{b}}$ & $42.4 \pm 1.9^{\mathrm{b}}$ \\
\hline
\end{tabular}

For each parameter, means within a column with different letters are significantly different $(p<0.05)$ according to the Tukey HSD test.
Table 3. Mean values ( \pm standard deviations) of the texture profile analysis.

\begin{tabular}{lrrr}
\hline \multirow{2}{*}{ Parameters } & \multicolumn{3}{c}{ Level of wet okara in beef burger } \\
\cline { 2 - 4 } & $0 \%($ control) & \multicolumn{1}{c}{$20 \%$} & \multicolumn{1}{c}{$25 \%$} \\
\hline Hardness $(\mathrm{mJ})$ & $111.5 \pm 17.2^{\mathrm{a}}$ & $119.9 \pm 20.6^{\mathrm{b}}$ & $133 \pm 22.91^{\mathrm{c}}$ \\
Chewiness $(\mathrm{mJ})$ & $242.8 \pm 29.2^{\mathrm{a}}$ & $208.3 \pm 25.0^{\mathrm{b}}$ & $197.9 \pm 23.8^{\mathrm{c}}$ \\
Springiness & $4.89 \pm 0.05^{\mathrm{a}}$ & $4.84 \pm 0.02^{\mathrm{b}}$ & $4.59 \pm 0.05^{\mathrm{c}}$ \\
Cohesiveness & $0.71 \pm 0.01^{\mathrm{a}}$ & $0.65 \pm 0.01^{\mathrm{b}}$ & $0.59 \pm 0.01^{\mathrm{c}}$ \\
\hline
\end{tabular}

For each parameter, means within a line with different letters are significantly different $(p<0.05)$ according to the Tukey HSD test. 
The instrumental analysis of colour (Table 3 ) indicated that the lowest luminosity $\left(\mathrm{L}^{*}, p<0.05\right)$ was observed in the control samples without okara ( $0 \%$ okara).

Higher lightness and yellowness values were found for beef burgers with higher okara content. This can be attributed to the cream colour of wet okara, which is similar to the colour of beef fat.

The values of $C^{*}$ (chroma) was higher $(\mathrm{p}<0.05)$ in the control ( $0 \%$ okara) and decreased with the addition of okara. Higher chroma indicates more saturation index of the red colour of the burger beef. The $\mathrm{h}^{\star}$ values were inversely related to $\mathrm{C}^{\star}$ values. The control samples showed the lowest values of $h^{\star}$ (less yellowish-tan). No differences were detected ( $p>0.05)$ for hue values between the beef burgers formulated with $20 \%$ and $25 \%$ of okara. Despite the differences in the $\mathrm{C}^{\star}$ and $\mathrm{h}^{\star}$ values, beef burgers made without okara (control) had similar visual appearance. The mean scores for juiciness, appearance, flavour, tenderness, and overall acceptability of the sensory evaluation of beef burgers are given in Table 4 .

Juiciness, appearance, tenderness, and overall acceptability of the burger beef formulated with $0 \%, 20 \%$ and $25 \%$ okara did not significantly differ $(p>0.05)$. Sensory analysis showed that the beef burgers made with okara had higher tenderness scores than those of the samples without okara (control). But due to the large variation among the sensory judges' scores, this difference was not statistically significant. The addition of okara in the form of a hydrated powder in the present study might explain such difference (MANSOUR; KHALIL, 1999). The soft texture of okara and higher moisture content might be contributing factors to the higher tenderness of beef burger formulated with okara. Okara improved tenderness but decreased $(p<0.05)$ springiness and cohesiveness of beef burger compared with those of the control samples (without okara). Similarly, Garzon et al. (2003) found a decrease in cohesiveness when replacing fat with carbohydrate-lipid composites in beef patties. These observations differ from the findings of Khalil (2000), who reported that beef patties formulated with modified corn starch were more cohesive and springy than those formulated with water alone.

Consumer acceptability of meat products is intrinsically related to their attributes of colour (appearance), tenderness, flavour, and juiciness (VENTURINI et al., 2011). The addition

Table 4. Mean values ( \pm standard deviations) of juiciness, appearance, flavour, tenderness, and overall acceptability of the sensory evaluation of the cooked beef burgers.

\begin{tabular}{lccc}
\hline \multirow{2}{*}{\multicolumn{1}{c}{$\begin{array}{c}\text { Sensory } \\
\text { attributes }\end{array}$}} & \multicolumn{3}{c}{ Level of wet okara in the beef burger } \\
\cline { 2 - 4 } & $0 \%$ & $20 \%$ & $25 \%$ \\
\hline Juiciness & $7.07 \pm 1.63^{\mathrm{a}}$ & $6.75 \pm 1.88^{\mathrm{a}}$ & $6.54 \pm 1.40^{\mathrm{a}}$ \\
Appearance & $6.82 \pm 1.25^{\mathrm{a}}$ & $6.43 \pm 1.83^{\mathrm{a}}$ & $6.29 \pm 1.54^{\mathrm{a}}$ \\
Flavour & $7.29 \pm 1.30^{\mathrm{a}}$ & $7.11 \pm 1.50^{\mathrm{a}}$ & $6.39 \pm 1.40^{\mathrm{b}}$ \\
Tenderness & $6.21 \pm 1.69^{\mathrm{a}}$ & $6.64 \pm 1.97^{\mathrm{a}}$ & $6.64 \pm 1.34^{\mathrm{a}}$ \\
Overall acceptability & $6.86 \pm 1.58^{\mathrm{a}}$ & $6.82 \pm 1.79^{\mathrm{a}}$ & $6.50 \pm 1.14^{\mathrm{a}}$ \\
\hline
\end{tabular}

For each attribute, means within a line with different letters are significantly different $(p<0.05)$ according to the Tukey HSD test. of okara significantly reduced flavour of beef burger in a dose dependent manner. The lower scores for flavour $(p<0.05)$ in beef burgers containing $25 \%$ wet okara can be attributed to the unpleasant taste of soy that masks the flavour of meat. The addition of soy extenders decreased the beefy flavour and increased off-flavour scores in both low-fat and high-fat beef patties (TURHAN; TEMIZ; SAGIR, 2007; BREWER et al., 1992). The use of soy proteins in meat products is limited due to their bitter taste, astringent mouth feel, and undesirable soy and beany flavour, which decreases the sensory quality of the final product (DELLA TORRE, 2004). The beef burgers with okara reached good acceptability index for juiciness, appearance, tenderness, and overall acceptability (71-81\%). Teixeira, Meinert and Barbetta (1987) stated that an acceptability index of at least $70 \%$ is necessary for a product to be considered accepted in terms of its sensorial properties.

\section{Conclusions}

It was found that the hardness score of the beef burgers increased with a concomitant decrease in the flavour score when the amount of okara increased up to $25 \%$. Juiciness, appearance, tenderness, and overall acceptability of the beef burgers formulated with wet okara (20\% or $25 \%)$ did not differ from those of the control ( $0 \%$ okara). Wet okara $(20 \%)$ can be effectively used as a non-meat protein source to produce reduced-fat beef burgers with satisfactory eating quality.

\section{Acknowledgements}

The authors acknowledge the "Conselho Nacional de Desenvolvimento Científico e Tecnológico” (CNPq) for granting the Scientific Initiation fellowship and Hyde Alimentos Ltda for the supply of wet okara.

\section{References}

APLEVICZ, K. S.; DEMIATE, I. M. Análises físico-químicas de prémisturas de pães de queijo e produção de pães de queijo com adição de okara. Ciência e Agrotecnologia, v. 31, n. 5, p. 1416-1422, 2007. http://dx.doi.org/10.1590/S1413-70542007000500022

ARIHARA, K. Strategies for designing novel functional meat products. Meat Science, v. 74, n. 1, p. 219-229, 2006. PMid:22062731. http:// dx.doi.org/10.1016/j.meatsci.2006.04.028

ASSOCIATION OF OFFICIAL ANALYTICAL CHEMISTS - AOAC. Official Methods of Analysis of the Association of Official Analytical Chemists. 18th ed. Maryland: AOAC, 2007. 1298 p.

BENGTSSON, H.; MONTELIUS, C.; TORNBERG, E. Heat-treated and homogenised potato pulp suspensions as additives in low-fat sausages. Meat Science, v. 88, n. 1, p. 75-78, 2011. PMid:21237576. http://dx.doi.org/10.1016/j.meatsci.2010.12.005

BOURNE, M. C. Texture profile analysis. Food Technology, v. 32, n. 7, p. 62-66, 1978.

BOWLES, S.; DEMIATE, I. M. Physicochemical characterization of the soymilk byproduct - okara. Ciência e Tecnologia de Alimentos, v. 26 , n. 3, p. 652-659, 2006. http://dx.doi.org/10.1590/S010120612006000300026

BRASIL. Ministério da Saúde. Portaria n² 27, de 13 de janeiro de 1998. Regulamento Técnico referente à Informação Nutricional 
Complementar. Diário Oficial da República Federativa do Brasil, Brasília, DF, 16 jan. 1998.

BRASIL. Ministério da Saúde. Resolução RDC n 360, de 23 de dezembro de 2003. Regulamento técnico sobre rotulagem nutricional de alimentos embalados. Diário Oficial da República Federativa do Brasil, Brasília, DF, 26 dez. 2003.

BREWER, M. S. et al. Some effects of sodium lactate on shelf-life, sensory, and physical characteristics of vacuum-packaged beef bologna. Journal of Food Quality, v. 15, n. 5, p. 369-382, 1992. http://dx.doi.org/10.1111/j.1745-4557.1992.tb00963.x

BREWER, M. S. Reducing the fat content in ground beef without sacrificing quality: A review. Meat Science, v. 91, n. 4, p. 385-395, 2012. PMid:22444664. http://dx.doi.org/10.1016/j. meatsci.2012.02.024

DAS, A. K. et al. Effect of full-fat soy paste and textured soy granules on quality and shelf-life of goat meat nuggets in frozen storage. Meat Science, v. 80, n. 3, p. 607-614, 2008. PMid:22063572. http:// dx.doi.org/10.1016/j.meatsci.2008.02.011

DELLA TORRE, J. C. M. Proteínas de soja e colágeno: validação das metodologias de quantificação e avaliação tecnológica do uso em produtos cárneos. 2004. $261 \mathrm{f}$. Tese (Doutorado)-Faculdade de Engenharia de Alimentos, Universidade Estadual de Campinas, Campinas, 2004. PMCid:1470845.

DESMOND, E. M.; TROY, D. J.; BUCKLEY, D. J. Comparative studies of nonmeat adjuncts used in the manufacture of low-fat beef burgers. Journal of Muscle Foods, v. 9, n. 3, p. 221-241, 1998. http://dx.doi. org/10.1111/j.1745-4573.1998.tb00657.x

GARZON, G. A. et al. Characteristics of low-fat beef patties formulated with carbohydrate-lipid composites. Journal of Food Science, v. 68, n. 6, p. 2050-2056, 2003.

GRIZOTTO, R. K. et al. Evaluation of the quality of a molded sweet biscuit enriched with okara flour. Ciência e Tecnologia de Alimentos, v. 30, p. 270-275, 2010. Suplemento 1.

HORITA C. N. et al. Physico-chemical and sensory properties of reduced-fat mortadella prepared with blends of calcium, magnesium and potassium chloride as partial substitutes for sodium chloride. Meat Science, v. 89, n. 4, p. 426-433, 2011. PMid:21645975. http:// dx.doi.org/10.1016/j.meatsci.2011.05.010

JACKSON, C. J. et al. Effects of processing on the content and composition of isoflavones during manufacturing of soy beverage and tofu. Process Biochemistry, v. 37, p. 1117-1123, 2001. http:// dx.doi.org/10.1016/S0032-9592(01)00323-5

KHALIL, A. H. Quality characteristics of low-fat beef patties formulated with modified corn starch and water. Food Chemistry, v. 68, n. 1, p. 61-68, 2000. http://dx.doi.org/10.1016/S0308-8146(99)00156-9

LI, B.; QIAO, M.; LU, F. Composition, nutrition, and utilization of okara (soybean residue) Food Reviews International, v. 28, n. 3, p. 231-252, 2012. http://dx.doi.org/10.1080/87559129.2011.595023
MA, C. Y. et al. Isolation and characterization of proteins from soymilk residue (okara). Food Research International. v. 29, n. 8, p. 799-805, 1997. http://dx.doi.org/10.1016/0963-9969(95)00061-5

MANSOUR, E. H.; KHALIL, A. H. Characteristics of low-fat beefburgers as influenced by various types of wheat fibres. Journal of the Science of Food and Agriculture, v. 79, n. 4, p. 493-498, 1999. http:// dx.doi.org/10.1002/(SICI)1097-0010(19990315)79:4\%3C493::AIDJSFA4\%3E3.0.CO;2-5

MATEOS-APARICIO, I. et al. Pea pod, broad bean pod and okara, potential sources of functional compounds. LWT - Food Science and Technology, v. 43, n. 9, p. 1467-1470, 2010.

PINTO, D. D. J.; CASTRO, P. S. Estudo preliminar da secagem do okara (resíduo do extrato aquoso de soja) para inativação dos fatores antinutricionais e conservação. Brazilian Journal of Food Technology, n. 18, p. 125-131, 2008. Preprint Series.

RINALDI, V. E. A.; NG, P. K. W.; BENNINK, M. R. Effects of extrusion on dietary fiber and isoflavone contents of wheat extrudates enriched with wet okara. Cereal Chemistry, v. 77, v. 2, p. 237-240, 2000.

SARIÇOBAN, C.; YILMAZ, M. T.; KARAKAYA, M. Response surface methodology study on the optimisation of effects of fat, wheat bran and salt on chemical, textural and sensory properties of patties. Meat Science, v. 83, n. 3, p. 397-403, 2009.

SELANI, M. M. et al. Wine industry residues extracts as natural antioxidants in raw and cooked chicken meat during frozen storage. Meat Science, v. 88, n. 3, p. 397-403, 2011. PMid:21342750. http:// dx.doi.org/10.1016/j.meatsci.2011.01.017

STONE, H.; SIDEL, J. L. Sensory evaluation practices. 3nd ed. London: Academic Press. 2004. 374 p.

TEIXEIRA, E.; MEINERT, E.; BARBETTA, P. A. Análise sensorial dos alimentos. Florianópolis: Ed. da UFSC, 1987. 182 p.

TURHAN, S.; TEMIZ, H.; SAGIR, I. Utilization of wet okara in lowfat beef patties. Journal of Muscle Foods, v. 18, p. 226-235, 2007. http://dx.doi.org/10.1111/j.1745-4573.2007.00081.x

VENTURINI, A. C. et al. Uncured fresh chicken sausage with reduced fat content. Ciência e Tecnologia de Alimentos, v. 31, n. 3, p. 629-634, 2011. http://dx.doi.org/10.1590/S010120612011000300012

WALISZEWSKI, K. N.; PARDIO, V.; CARREON, E. Physicochemical and sensory properties of corn tortillas made from nixtamalized corn flour fortified with spent soymilk residue (okara). Journal of Food Science, v. 67, n. 8, p. 3194-3197, 2002. http://dx.doi. org/10.1111/j.1365-2621.2002.tb08881.x

YILMAZ, I.; DAGLIOGLU, O. The effect of replacing fat with oat bran on fatty acid composition and physicochemical properties of meatballs. Meat Science, v. 65, n. 2, p. 819-823, 2003. http://dx.doi. org/10.1016/S0309-1740(02)00286-3 